\title{
Vertical profile of peroxyacetyl nitrate (PAN) from MIPAS-STR measurements over Brazil in February 2005 and its contribution to tropical UT NO $\mathrm{N}_{\mathrm{y}}$ partitioning
}

\author{
C. Keim ${ }^{1,}$, G. Y. Liu ${ }^{1, * *}$, C. E. Blom ${ }^{1}$, H. Fischer ${ }^{1}$, T. Gulde ${ }^{1}$, M. Höpfner ${ }^{1}$, C. Piesch ${ }^{1}$, F. Ravegnani ${ }^{2}$, A. Roiger ${ }^{3}$, \\ H. Schlager ${ }^{3}$, and N. Sitnikov ${ }^{4}$ \\ ${ }^{1}$ Institut für Meteorologie und Klimaforschung, Forschungszentrum Karlsruhe, Germany \\ ${ }^{2}$ Institute of Atmospheric Sciences and Climate (ISAC-CNR), Bologna, Italy \\ ${ }^{3}$ Institut für Physik der Atmosphäre, Deutsches Zentrum für Luft- und Raumfahrt, Wessling, Germany \\ ${ }^{4}$ Central Aerological Observatory, Dolgoprudny, Moscow region, Russia \\ *now at: Laboratoire Interuniversitaire des Systèmes Atmosphériques (LISA) CNRS/Univ. Paris 12 et 7, France \\ *** now at: Department of Earth and Atmospheric Science, City College of New York, USA
}

Received: 18 February 2008 - Published in Atmos. Chem. Phys. Discuss.: 9 April 2008

Revised: 28 July 2008 - Accepted: 28 July 2008 - Published: 26 August 2008

\begin{abstract}
We report on the retrieval of PAN $\left(\mathrm{CH}_{3} \mathrm{C}(\mathrm{O}) \mathrm{OONO}_{2}\right)$ in the upper tropical troposphere from limb measurements by the remote-sensor MIPASSTR on board the Russian high altitude research aircraft M55-Geophysica. The measurements were performed close to Araçatuba, Brazil, on 17 February 2005. The retrieval was made in the spectral range $775-820 \mathrm{~cm}^{-1}$ where PAN exhibits its strongest feature but also more than 10 species interfere. Especially trace gases such as $\mathrm{CH}_{3} \mathrm{CCl}_{3}$, CFC113, CFC-11, and CFC-22, emitting also in spectrally broad not-resolved branches, make the processing of PAN prone to errors. Therefore, the selection of appropriate spectral windows, the separate retrieval of several interfering species and the careful handling of the water vapour profile are part of the study presented.

The retrieved profile of PAN has a maximum of about $0.14 \mathrm{ppbv}$ at $10 \mathrm{~km}$ altitude, slightly larger than the lowest reported values $(<0.1 \mathrm{ppbv})$ and much lower than the highest reported in the literature $(0.65 \mathrm{ppbv})$. Besides the $\mathrm{NO}_{\mathrm{y}}$ constituents measured by MIPAS-STR $\left(\mathrm{HNO}_{3}, \mathrm{ClONO}_{2}\right.$, $\mathrm{HO}_{2} \mathrm{NO}_{2}$, PAN), the in situ instruments aboard the Geophysica provide simultaneous measurements of $\mathrm{NO}, \mathrm{NO}_{2}$, and the sum $\mathrm{NO}_{\mathrm{y}}$. Comparing the sum of in-situ and remotely derived $\mathrm{NO}+\mathrm{NO}_{2}+\mathrm{HNO}_{3}+\mathrm{ClONO}_{2}+\mathrm{HO}_{2} \mathrm{NO}_{2}+\mathrm{PAN}$ with total
\end{abstract}

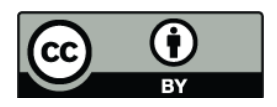

Correspondence to: M. Höpfner (michael.hoepfner@imk.fzk.de)
$\mathrm{NO}_{\mathrm{y}}$ a deficit of $30-40 \%(0.2-0.3 \mathrm{ppbv})$ in the troposphere remains unexplained whereas the values fit well in the stratosphere.

\section{Introduction}

PAN $\left(\mathrm{CH}_{3} \mathrm{C}(\mathrm{O}) \mathrm{OONO}_{2}\right)$ is the most common member of peroxyacyl nitrates playing an important role in tropospheric chemistry. In high concentrations - higher, than up to now measured in the atmosphere - it is known to be eye irritant and phytotoxic to plants. PAN was first discovered in a Los Angeles photochemical smog episode (Stephens et al., 1956). Biomass burning was also suggested to be a significant source of PAN (Holzinger et al., 2005). The formation of PAN in the atmosphere involves hydrocarbons (paraffins, olefins, aromatics) and oxides of nitrogen. It is initiated by the reaction of $\mathrm{OH}$ with hydrocarbons. After intermediate reactions involving acetaldehyde, the acetyl radical and molecular oxygen, the peroxyacetyl radical $\left(\mathrm{CH}_{3} \mathrm{CO}_{3}\right)$ is formed which further reacts with $\mathrm{NO}_{2}$ to PAN (Singh, 1987).

The lifetime of PAN in the lower troposphere is in the order of hours and is dominated by thermolysis. In the upper troposphere, the lifetime, dominated by photolysis, is of the order of months, or even longer in dark Arctic regions (Talukdar et al., 1995; Kirchener et al., 1999). Median $\mathrm{PAN} / \mathrm{NO}_{\mathrm{y}}$ ratios of more than 0.6 at altitudes from $4 \mathrm{~km}$

Published by Copernicus Publications on behalf of the European Geosciences Union. 
to $8 \mathrm{~km}$ have been observed in long-range transported Asian pollution plumes (Roberts et al., 2004). For details on the formation and distribution of PAN see Warneck (1999) and Finlayson-Pitts and Pitts (2000).

Although PAN concentrations as high as $0.65 \mathrm{ppbv}$ (up to $8 \mathrm{~km}$ ) have been observed (Roberts et al., 2004), its low concentrations $(<0.1 \mathrm{ppbv})$ in relatively clean background conditions (see e.g. measurements in the south Atlantic by Singh, 1996) make it difficult to measure. Various in situ techniques have been used to determine the volume mixing ratios of PAN in the atmosphere. These are Fourier transform infrared spectroscopy (FTIR) (Stephens et al., 1956; Hanst et al., 1982), gas chromatography with electron capture detection (GC/ECD) (Lovelock, 1961; Müller and Rudolph, 1989), gas chromatography with luminol-chemiluminescence detection (GC/LCD) (Gaffney et al., 1998), proton transfer reaction mass spectrometry (PTR-MS) (Hansel et al., 1995) coupled with a selected ion flow drift tube (SIFDT) method (Hansel and Wisthaler, 2000), gas chromatography / negative ion chemical ionization mass spectrometry (GC/NICI MS) (Tanimoto et al., 2001), thermal dissociation-chemical ionization mass spectrometry (TD-CIMS) (Slusher et al., 2004), and thermal dissociation-laser induced fluorescence (TD-LIF) (Day et al., 2002). The latter only detects sum peroxy nitrates, among those PAN is typically $80-90 \%$.

Remote sensing in the infrared provides an alternative and independent method for the measurement of PAN. From occultation measurements of ACE-FTS onboard SCISAT-1 it was possible to retrieve PAN in a young biomass burning plume (Coheur et al., 2007). Recently, Remedios et al. (2007a) have shown the clear presence of the signatures of PAN in the emission spectra obtained by the balloon born MIPAS. Global upper tropospheric PAN distributions were derived from MIPAS/Envisat spectra by Glatthor et al. (2007).

In this paper we report the retrieval of PAN from measurements of MIPAS-STR (Michelson Interferometer for Passive Atmosphere Sounding-STRatospheric aircraft, Piesch et al., 1996) an instrument operated on board the high-altitude aircraft Geophysica. The work was initiated by the observation that large differences exist in the upper troposphere (above $10 \mathrm{~km}$ ) between MIPAS-STR measurements of $\mathrm{HNO}_{3}$ and coincident in situ measurements of $\mathrm{NO}_{\mathrm{y}}-\mathrm{NO}$ by SIOUX (StratospherIc Observation Unit for nitrogen oXides, Schmitt, 2003) also aboard the Geophysica.

In the following we give a short description of the MIPASSTR instrument and its measurement strategy, an overview of the flight of 17 February 2005 and compare $\mathrm{HNO}_{3}$ data from MIPAS-STR with coincident in-situ measurements of $\left(\mathrm{NO}_{\mathrm{y}}-\right.$ $\mathrm{NO}-\mathrm{NO}_{2}$ ) to obtain an upper limit PAN profile (Sect. 2). Further we give a simulation on the feasibility of detecting PAN from the MIPAS-STR observations (Sect. 3), relevant general details on the data processing (Sect. 4) and finally the retrieval of PAN from the measured spectra, including the er- ror estimation (Sect. 5). The last section gives a summary and a discussion of the results.

\section{MIPAS-STR measurements on 17 February 2005}

\subsection{The MIPAS-STR instrument}

MIPAS-STR is a cryogenic Fourier transform emission sounder operating in the middle infrared (Fischer and Oelhaf, 1996; Keim et al., 2004). The emission method allows limb and upward viewing, yielding about $2 \mathrm{~km}$ vertical resolution below the flight level (up to $20 \mathrm{~km}$ ). Reduced vertical information above the flight level is obtained by upward measurements with several elevation angles. The final results are 2-dimensional distributions of the trace gases along the flight track in an altitude range covering the lowest stratosphere and the upper troposphere.

The first deployment of MIPAS-STR was made during the Antarctic campaign APE-GAIA in 1999 (Höpfner et al., 2000). The performance of the instrument has been considerably improved in recent years. The pointing of the limb measurements has been operated at fixed tangent heights between $6 \mathrm{~km}$ and the flight altitude with a spacing of $1 \mathrm{~km}$. Considering the instrumental field of view of 0.44 degrees (FWHM) over-sampling by a factor 2-3 was applied at the lower tangent heights. In addition upward measurements at elevation angles of $0,1,3$ and 10 degrees, as well as zenith and cold blackbody $(210 \mathrm{~K})$ measurements were performed. Twosided interferograms were obtained with a maximum optical path difference $\mathrm{L}$ of $14.4 \mathrm{~cm}$, resulting in an unapodised spectral resolution $(1 / 2 \mathrm{~L})$ of $0.035 \mathrm{~cm}^{-1}$. For a flight altitude of $19 \mathrm{~km}$ the complete sequence, including calibration, takes $200 \mathrm{~s}$. This results in a horizontal resolution in flight direction of about $36 \mathrm{~km}$. The data shown in this paper are obtained from channel 1 , which covers the wavenumber range of $770-970 \mathrm{~cm}^{-1}$.

\subsection{Flight scenario}

The flight track of the Geophysica with the location of the tangent points of MIPAS-STR limb sequences is given in Fig. 1. From Araçatuba $\left(21.2^{\circ} \mathrm{S}, 50.4^{\circ} \mathrm{W}\right)$ the flight was conducted northbound and returned south on a straight track from $14^{\circ} \mathrm{S}$ to $23^{\circ} \mathrm{S}$. Optically thick clouds were observed in the northern part of this leg which prevented trace gas retrieval for that region. However, cloudless condition were found in the southern part, just before the descent. The red rectangle in Fig. 1 indicates the tangent points of six cloud free limb sequences measured between 13:05 and 13:20 UTC (about 10 a.m. local time). These six limb sequences cover the track of the aircraft on the descent, which started at the southernmost point of the path. The flight thus gives an excellent opportunity to compare the MIPAS-STR profile with in situ data measured during descent. 


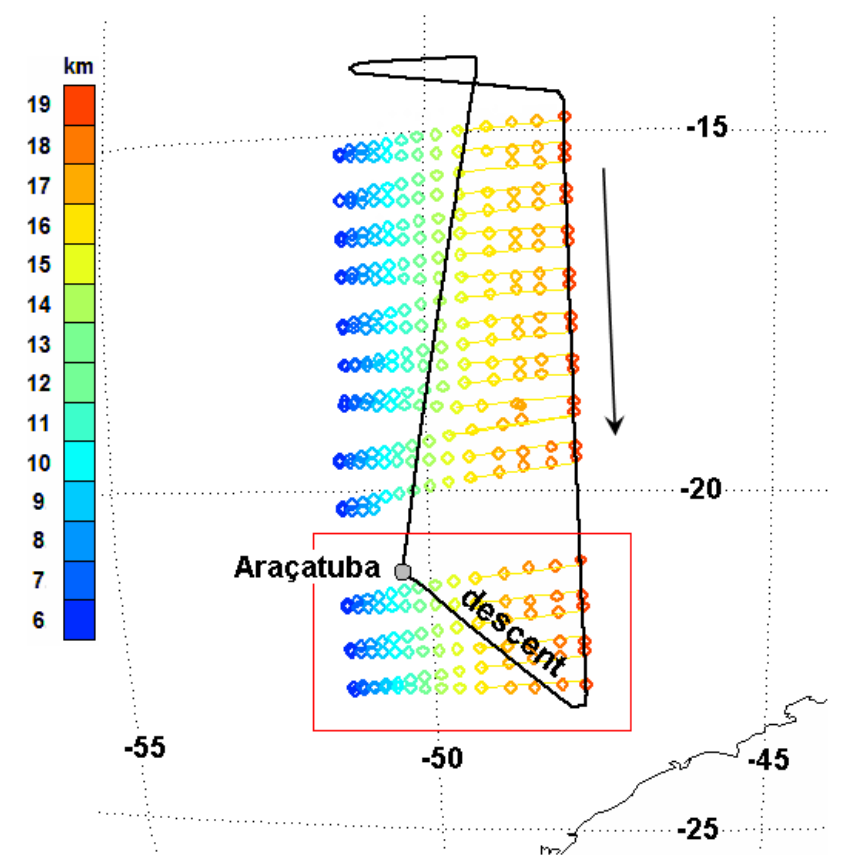

Fig. 1. Flight track of Geophysica and location of the tangent points of the MIPAS-STR instrument on 17 February 2005. The black arrow denotes the flight direction. The colour coding of the tangent points indicates their altitude, from blue for the lowest altitude at $6 \mathrm{~km}$ to orange at the aircraft flight level at $19 \mathrm{~km}$. The red rectangle surrounds the six cloud-free sequences, used in this work and the aircrafts descent, where the in-situ profiles are located.

\subsection{The SIOUX instrument}

Nitric oxide (NO) and total reactive nitrogen $\left(\mathrm{NO}_{\mathrm{y}}\right)$ were measured with the SIOUX (Stratospheric Observation Unit for nitrogen oXides) instrument. SIOUX includes a two-channel high sensitivity NO detector using gas-phase $\mathrm{O}_{3} / \mathrm{NO}$-chemiluminescence technique. For detection of total reactive nitrogen (defined as $\mathrm{NO}_{\mathrm{y}}=\mathrm{NO}+\mathrm{NO}_{2}+\mathrm{NO}_{3}+$ $\mathrm{HNO}_{3}+\mathrm{HNO}_{2}+\mathrm{HNO}_{4}+\mathrm{PAN}+\mathrm{RONO}_{2}+2 \cdot \mathrm{N}_{2} \mathrm{O}_{5}+$ halogen nitrates + organic nitrates + aerosol nitrates), higher oxidised nitrogen compounds are reduced to NO using a heated $\left(300^{\circ} \mathrm{C}\right)$ catalytic gold converter operated with addition of CO (e.g., Fahey et al., 1985). The conversion efficiency of the $\mathrm{NO}_{\mathrm{y}}$ converter to $\mathrm{HCN}$ was investigated in laboratory tests and amounts to $2-15 \%$ of the $\mathrm{HCN}$ mixing ratio increasing with increasing ozone concentration. In the troposphere this may result in an artifact $\mathrm{NO}_{\mathrm{y}}$ signal of $4 \mathrm{pptv}$ $\left(<1 \%\right.$ of the $\mathrm{NO}_{\mathrm{y}}$ signal) for a $\mathrm{HCN}$ mixing ratio of $200 \mathrm{pptv}$. Further details of the measurement technique are given in Ziereis et al. (2000). The SIOUX instrument has already been used during several field campaigns on board the Geophysica (Grooß et al., 2005; Voigt et al., 2005, 2006). It is housed in a container under the right wing of the Geophysica. Ambient sample air is passed through a rearward fac-

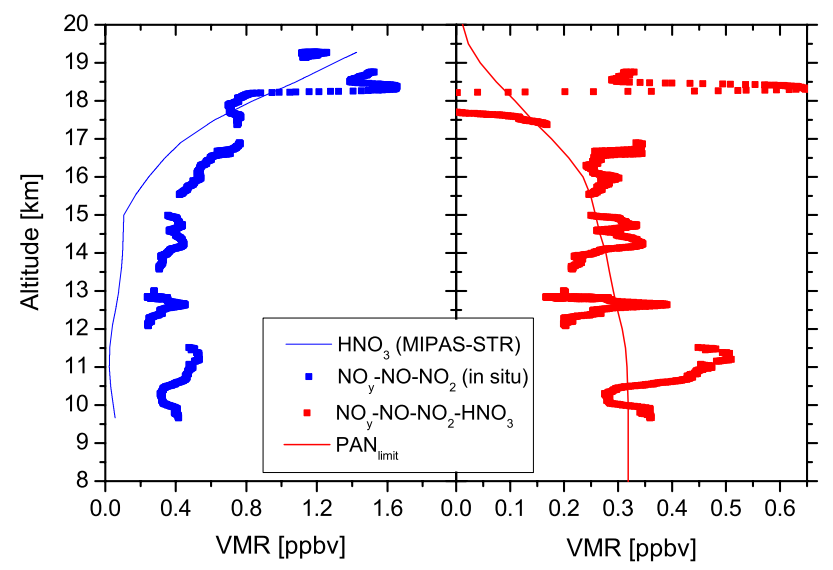

Fig. 2. Comparison of $\mathrm{HNO}_{3}$ from MIPAS-STR with in situ measured $\mathrm{NO}_{\mathrm{y}}-\mathrm{NO}-\mathrm{NO}_{2}$ (left) and the difference of $\mathrm{NO}_{\mathrm{y}}-\mathrm{NO}-\mathrm{NO}_{2}-$ $\mathrm{HNO}_{3}$ (right). In the right panel we give also the smoothed difference used in Sect. 4.6.

ing inlet to avoid sampling of larger aerosol particles. Small aerosols $(<1 \mu \mathrm{m})$ may enter the inlet, however, the contribution of nitrate contained in these particles to the $\mathrm{NO}_{\mathrm{y}}$ signal is considered negligible. The overall accuracy of the NO and $\mathrm{NO}_{\mathrm{y}}$ measurements is $7 \%$ and $12 \%(1 \sigma)$, respectively, with a time resolution of $1 \mathrm{~s}$.

The concentration of $\mathrm{NO}_{2}$ has been be calculated assuming a photochemical steady state between daytime $\mathrm{NO}_{2}$ and NO according to Eq. (1) (e.g., Schlager et al., 1997).

$$
\begin{aligned}
& \mathrm{NO}_{2}+h v \rightarrow \mathrm{NO}+\mathrm{O} \\
& \mathrm{O}+\mathrm{O}_{2} \rightarrow \mathrm{O}_{3} \\
& \mathrm{NO}+\mathrm{O}_{3} \rightarrow \mathrm{NO}_{2}+\mathrm{O}_{2} \\
& {\left[\mathrm{NO}_{2}\right]=[\mathrm{NO}] \times\left[\mathrm{O}_{3}\right] \times \mathrm{k}(\mathrm{T}) / \mathrm{J}_{\mathrm{NO}_{2}} }
\end{aligned}
$$

where square brackets indicate concentrations, $k(T)$ denotes the temperature-dependent rate coefficient of the reaction of $\mathrm{O}_{3}$ with $\mathrm{NO}$, and $\mathrm{J}_{\mathrm{NO}_{2}}$ is the $\mathrm{NO}_{2}$ photolysis frequency. The $\mathrm{J}_{\mathrm{NO}_{2}}$ values are calculated with the radiative transfer model of Ruggaber et al. (1994). The $\mathrm{O}_{3}$ concentrations are taken from measurements of FOZAN (Fast OZone ANalyzer, Ulanovsky et al., 2001), an other in situ instrument aboard the Geophysica, and the temperatures from a high-precision TDC (thermodynamic complex) sensor (Rosemount sensor customized at CAO, Central Aerological Observatory, Dolgoprudny, Russia) also aboard the same aircraft.

Individual uncertainties for $\mathrm{O}_{3}, \mathrm{k}$, and $\mathrm{J}_{\mathrm{NO}_{2}}$ are $5 \%, 35 \%$, and $25 \%$, respectively. The overall accuracy of the $\mathrm{NO}_{2}$ calculation is $25 \%(1 \sigma)$. 


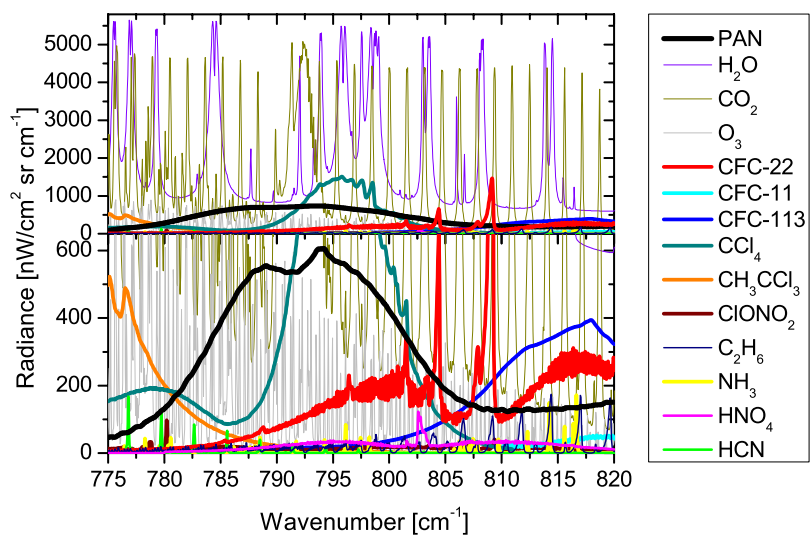

Fig. 3. Simulated spectra in the broad-band range of PAN (black) for a tangent height of $8 \mathrm{~km}$. The lower plot is a zoom of the upper one in y-direction.

2.4 Comparison of MIPAS-STR measured $\mathrm{HNO}_{3}$ with in situ measured $\mathrm{NO}_{\mathrm{y}}-\mathrm{NO}-\mathrm{NO}_{2}$

In Fig. 2 the mean $\mathrm{HNO}_{3}$ volume mixing ratio (vmr) from the six southernmost limb sequences (see Fig. 1) is compared to the in situ observation of $\mathrm{NO}_{\mathrm{y}}-\mathrm{NO}-\mathrm{NO}_{2}$ during descent. $\mathrm{HNO}_{3}$ was retrieved in its $v 5$ and $2 v 9$ bands as described in Wang et al. (2007) using the MIPAS spectroscopic database version PF3.1 (Flaud et al., 2003). $\mathrm{NO}_{\mathrm{y}}$ and $\mathrm{NO}$ are measured directly by SIOUX, while $\mathrm{NO}_{2}$ is calculated as described above. The vmr profiles of $\mathrm{ClONO}_{2}$ and $\mathrm{HO}_{2} \mathrm{NO}_{2}$, also included in $\mathrm{NO}_{\mathrm{y}}$, were retrieved from the MIPAS-STR measurements (see Höpfner et al. (2007) and Stiller et al. (2007) for the method), but due to their very low vmr (see Figs. 5 and 13) neglected in the comparison.

The altitude of the cold point tropopause (see Fig. 12) is about $18 \mathrm{~km}$. Below this altitude, $\mathrm{NO}_{\mathrm{y}}-\mathrm{NO}-\mathrm{NO}_{2}$ is always higher than $\mathrm{HNO}_{3}$ by up to 0.32 ppbv. In the following we investigate how much of this difference can be attributed to PAN.

\section{Spectral simulations for PAN}

A well suited band for mid-IR PAN analysis is located between 775 and $820 \mathrm{~cm}^{-1}$ (Glatthor et al., 2007; Remedios et al., 2007a). To indicate the contribution of different atmospheric trace species in this spectral region we show simulations performed with KOPRA (Karlsruhe Optimised and Precise Radiative transfer Algorithm, Stiller et al., 2000) for a tangent height of $8 \mathrm{~km}$ located at the southern part of the flight. In total 38 different trace gases are considered, the 14 strongest radiances are shown in Fig. 3. The band of PAN is mainly interfered by $\mathrm{CO}_{2}, \mathrm{H}_{2} \mathrm{O}, \mathrm{O}_{3}, \mathrm{CCl}_{4}, \mathrm{CFC}-22$, CFC113, $\mathrm{CH}_{3} \mathrm{CCl}_{3}$, and $\mathrm{ClONO}_{2}$. The infrared cross-section data for PAN at $295 \mathrm{~K}$ (Allen et al., 2005a) and the newer data at lower temperatures of $273 \mathrm{~K}$, and $250 \mathrm{~K}$ (Allen et al.,

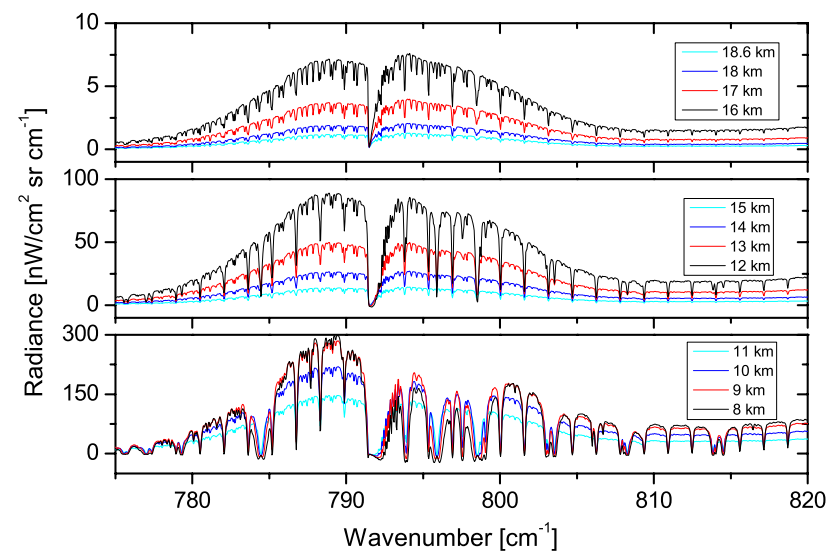

Fig. 4. Simulated difference spectra (with- without PAN) in the broad-band range of PAN for all tangent heights from 8 to $18.6 \mathrm{~km}$. The noise level of MIPAS-STR is about $15 \mathrm{nW} /\left(\mathrm{cm}^{2} \mathrm{sr} \mathrm{cm}^{-1}\right)$

2005b) are adopted in this paper. For the simulation, the temperature profile is taken from the ECMWF model (Fig. 12 supports this choice as reasonable) and the vmr profiles for all gases except for $\mathrm{H}_{2} \mathrm{O}$ and PAN are taken from a tropical climatology (Remedios et al., 2007b). For PAN a midlatitude profile of the MOZART Model (Model for OZone And Related chemical Tracers Horowitz et al., 2003) is used. The water profile is estimated from in situ measurements of FLASH (FLuorescence Airborne Stratospheric Hygrometer, Sitnikov et al., 2007) and FISH (Fast In situ Stratospheric Hygrometer, Zöger et al., 1999) aboard the Geophysica (see Fig. 6).

The sensitivity of the MIPAS-STR observation to PAN is demonstrated by plotting simulated difference spectra (withwithout PAN) for various tangent heights between 8 and 18.6 km (see Fig. 4).

In small spectral regions, the information on PAN is reduced due to saturation caused by interfering trace gases. This is the case around the $\mathrm{CO}_{2}$ Q-branch $\left(792 \mathrm{~cm}^{-1}\right)$ and at the position of strong $\mathrm{CO}_{2}$ and $\mathrm{H}_{2} \mathrm{O}$ lines. Apart from these regions the radiance abates rather quickly with increasing tangent height. This quick decrease is not surprising, the emitted radiance is (mainly) proportional to the concentration of the trace gas and via Planck's law also dependent on its temperature. As the temperature and the pressure (drives the concentration, if not compensated by a strong vmr increase) decrease with increasing altitude, the radiance decreases. At 13,14, and $15 \mathrm{~km}$, the maximum radiance is only 50,25 , and $12.5 \mathrm{nW} /\left(\mathrm{cm}^{2} \mathrm{srcm}^{-1}\right)$, respectively, comparable with the spectral noise $\left(15 \mathrm{nW} /\left(\mathrm{cm}^{2} \mathrm{srcm}^{-1}\right)\right)$ in the single MIPAS-STR spectra.

However, with the high resolution spectra the broadly emitting PAN can be retrieved by multi-line retrieval from much lower radiances. In the present work 1171 independent spectral points were used to obtain a PAN profile. 


\section{Data processing}

\subsection{Level-1 processing}

Level-1 processing of the MIPAS-STR data provides the input data for the subsequent profile retrieval. Basically, it converts raw interferograms of the atmospheric measurements stored during the flight into radiometrically calibrated atmospheric spectra for each tangent height or elevation angle. The spectral gain and offset of the instrument were obtained from the zenith and cold blackbody measurements of each individual sequence. The zenith spectra were corrected for the contained atmospheric features. Level-1 processing also provides the auxiliary data which are derived from the stored housekeeping information as well as from the line of sight calibration and the field of view measurements made before and after the flight. The auxiliary data include information on the corrected flight altitudes, elevation- and azimuth angles, and relevant instrument parameters.

\subsection{Level-2 processing}

Vertical profiles of the atmospheric parameters (vmr of gases, temperature, pressure and absorption/emission of aerosols) are retrieved by use of the atmospheric radiative transfer model KOPRA and its inversion algorithm KOPRAFIT. The profiles are iteratively changed to minimise the residuum between measured spectra and forward calculated spectra of a complete sequence. Regularisation of the profile shape against an a priori profile is necessary for each retrieved atmospheric parameter because the chosen retrieval grid $(0.5 \mathrm{~km})$ is finer than the achievable vertical resolution. In KOPRAFIT the Tikhonov-Philips regularisation method (Tikhonov, 1963; Phillips, 2003) was adopted:

$$
\begin{aligned}
\boldsymbol{x}_{i+1}= & \boldsymbol{x}_{i}+\left(\mathbf{K}_{i}^{T} \mathbf{S}_{y}^{-1} \mathbf{K}_{i}+\gamma \mathbf{L}^{T} \mathbf{L}\right)^{-1} \\
& {\left[\mathbf{K}_{i}^{T} \mathbf{S}_{y}^{-1}\left(\boldsymbol{y}-f\left(\boldsymbol{x}_{i}\right)\right)+\gamma \mathbf{L}^{T} \mathbf{L}\left(\boldsymbol{x}_{a}-\boldsymbol{x}_{i}\right)\right] }
\end{aligned}
$$

where $i$ denotes the iteration index; $\boldsymbol{x}$ the vector with the unknowns; $\boldsymbol{x}_{\boldsymbol{a}}$ the a priori values; $\boldsymbol{y}$ the measurement vector; $\mathbf{S}_{\mathbf{y}}$ the measurement covariance matrix of $\boldsymbol{y} ; f$ the forward model; $\mathbf{K}$ the spectral derivatives matrix; $\gamma$ the regularisation parameter and $\mathbf{L}$ the first derivative regularisation operator.

The regularisation strength is chosen as small as possible, just large enough to avoid oscillations in the resulting profile. The achieved vertical resolution of the retrieved profile is the FWHM (full width at half maximum) of the columns of the averaging kernel matrix, given by:

$$
\mathbf{A}=\left(\mathbf{K}_{i}^{T} \mathbf{S}_{y}^{-1} \mathbf{K}_{i}+\gamma \mathbf{L}^{T} \mathbf{L}\right)^{-1} \mathbf{K}_{i}^{T} \mathbf{S}_{y}^{-1} \mathbf{K}_{i}
$$

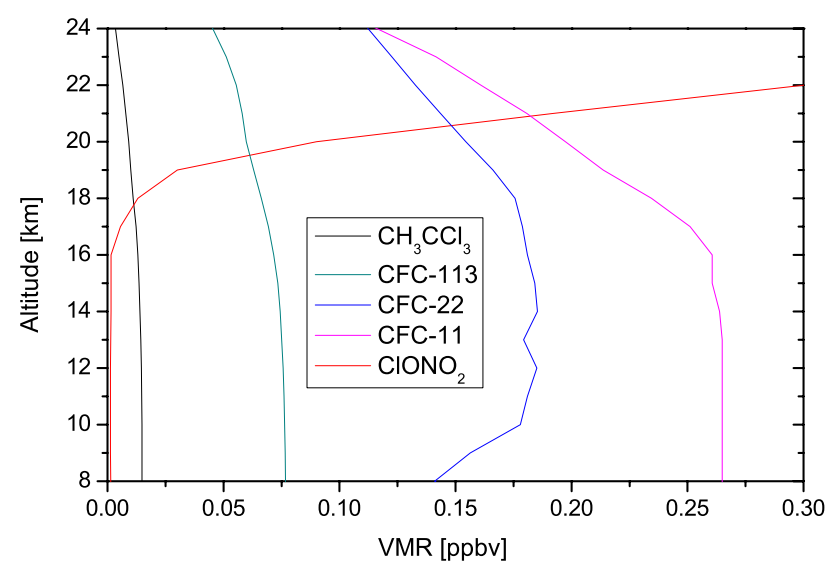

Fig. 5. Vertical profiles of five interfering species determined before the retrieval of PAN.

\subsection{PAN retrieval method}

Here we describe the strategy used for the retrieval of PAN. To minimise the error contribution from spectral noise, we have averaged all spectra of the same tangent height/elevation angle within the six southernmost limb sequences (see Fig. 1), which reduces the noise from 15 to $6 \mathrm{nW} /\left(\mathrm{cm}^{2} \mathrm{sr} \mathrm{cm}^{-1}\right)$. The MIPAS-STR spectra are averaged over the same region where the in situ measurements while the descent took place. The small variability of the individual spectra and also of the 6 individual profiles (e.g. of temperature and CFC-11) permits us to do the average and the comparison with the in situ profiles. Furthermore, we have used all spectral points between 775 and $820 \mathrm{~cm}^{-1}$, with the exception of the region 790-794 $\mathrm{cm}^{-1}$. We excluded this interval to avoid any error on the retrieval from line-mixing of the $\mathrm{CO}_{2}$ Q-branch located there.

A summary of atmospheric parameters (12 species and temperature) that have been considered in the retrieval scheme is given in Table 1. Among those parameters, five species $\left(\mathrm{CH}_{3} \mathrm{CCl}_{3}, \mathrm{CFC}-113\right.$, CFC-22, CFC-11, and $\mathrm{ClONO}_{2}$ ) have been determined in steps previous to the PAN retrieval and are kept constant. The remaining profiles are fitted simultaneously with PAN.

$\mathrm{ClONO}_{2}$ is fixed to the profile derived from the nearby $v_{4}$ Q-branch in the interval 779.5-781 $\mathrm{cm}^{-1}$ (Höpfner et al., 2007). CFC-11 has been determined on the basis of the major band in the interval $838-856 \mathrm{~cm}^{-1}$ (von Clarmann et al., 2007a) and CFC-22 has been obtained from its signature at $828.7-829.4 \mathrm{~cm}^{-1}$ (Moore and Remedios, 2008). $\mathrm{CH}_{3} \mathrm{CCl}_{3}$ and $\mathrm{CFC}-113$ profiles are firstly estimated from the tropic climatology and then scaled to remove their spectral signatures from the residuum. The scaling factor corrects the profiles for the annual decrease.

The vmr profiles of all five pre-determined species are plotted in Fig. 5. 
Table 1. Adjusted atmospheric parameter during the PAN retrieval.

\begin{tabular}{lll}
\hline Parameter & Handling & Source of a priori profile \\
\hline Temperature & Cofitted & ECMWF \\
PAN & Cofitted & model (MOZART) $\left(\right.$ PAN $\left._{\text {a priori }}\right)$ \\
$\mathrm{H}_{2} \mathrm{O}$ & Cofitted & Pre-determined (see Sect. 4.5) \\
$\mathrm{O}_{3}$ & Cofitted & Climatology \\
$\mathrm{CCl}_{4}$ & Cofitted & Climatology \\
$\mathrm{HCN}$ & Cofitted & Climatology \\
$\mathrm{C}_{2} \mathrm{H}_{6}$ & Cofitted & Climatology \\
$\mathrm{NH}_{3}$ & Cofitted & Climatology \\
$\mathrm{ClONO}_{2}$ & Pre-determined & MIPAS-STR \\
$\mathrm{CFC}_{2} 11$ & Pre-determined & MIPAS-STR \\
$\mathrm{CFC}_{2} 22$ & Pre-determined & MIPAS-STR \\
$\mathrm{CH} \mathrm{CCl}_{3}$ & Pre-determined & Modified Climatology \\
$\mathrm{CFC}_{2} 113$ & Pre-determined & Modified Climatology \\
\hline
\end{tabular}

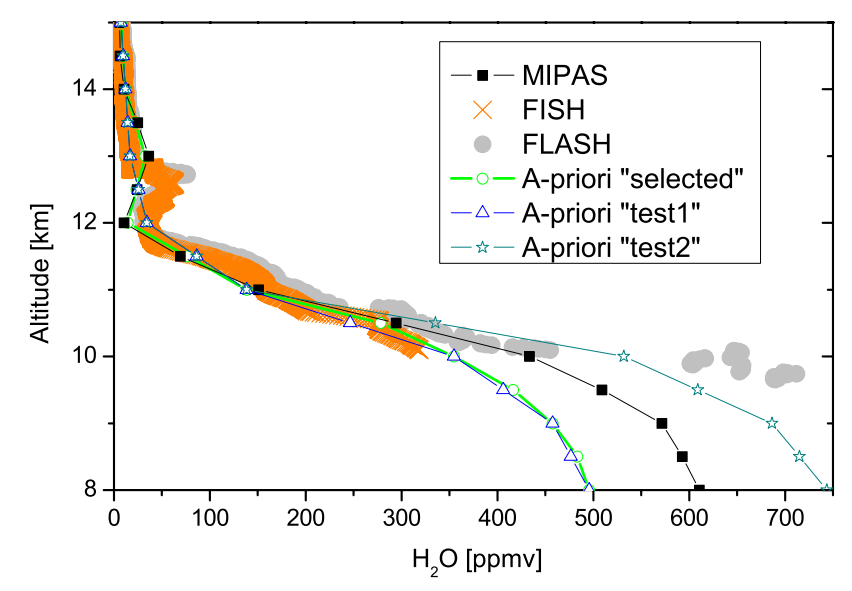

Fig. 6. The retrieved $\mathrm{H}_{2} \mathrm{O}$ profile (simultaneously fitted with

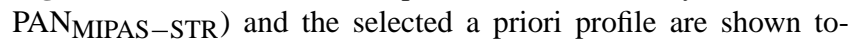
gether with in situ data from the FLASH and FISH instruments and two modified a priori profiles (test ${ }_{1}$, test 2 ), used for error estimation.

As a priori vmr profile for PAN $\left(\mathrm{PAN}_{\mathrm{a}}\right.$ priori $)$ a mid-latitude profile of the MOZART model is used (see Fig. 7). Beside trace gases and temperature we determine a continuum extinction profile for aerosols and a tangent height constant radiation offset for minor calibration errors.

Water continuum emission and possible aerosol broadband emission increase with decreasing tangent altitude. Both affect the baseline of the spectra. As the retrieval of PAN is sensitive on the quality of the baseline, we did not use spectra below $8 \mathrm{~km}$ altitude. The continuum contribution in these spectra exceed our threshold of $400 \mathrm{nW} /\left(\mathrm{cm}^{2} \mathrm{srcm}^{-1}\right)$ in the laser band region $\left(960 \mathrm{~cm}^{-1}\right)$.

\subsection{Determination of the $\mathrm{H}_{2} \mathrm{O}$ a priori profile}

Although $\mathrm{H}_{2} \mathrm{O}$ is simultaneously fitted with PAN, an impact of the applied a priori profile for water vapour on the PAN

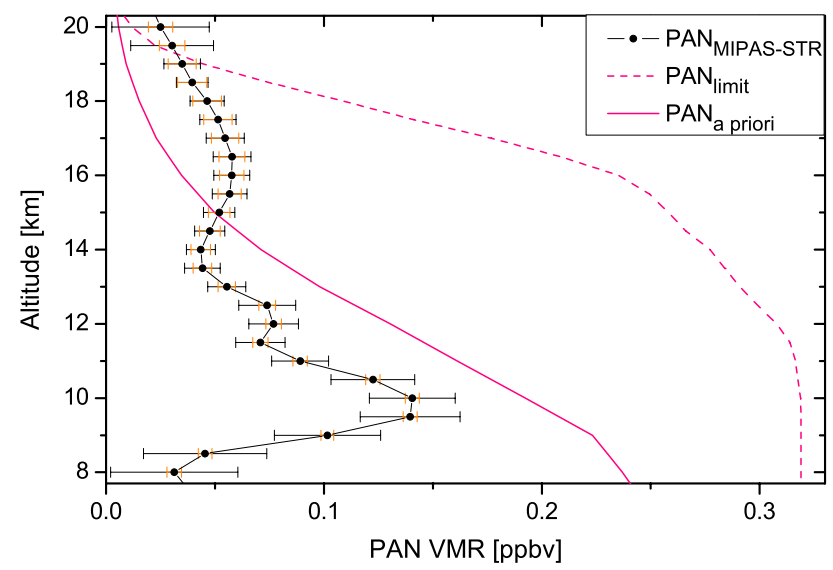

Fig. 7. PAN vertical profile retrieved from MIPAS-STR (17 February $2005,13: 15 \mathrm{UTC}$; location: $22.0^{\circ} \mathrm{S}$ and $\left.47.7^{\circ} \mathrm{W}\right)$. The error bars give the noise error (red) and the estimated total error (black). Also shown are the a priori profile and the upper limit corresponding to the $\mathrm{NO}_{\mathrm{y}}$ measurements.

result has been observed. The use of a climatological $\mathrm{H}_{2} \mathrm{O}$ a priori profile resulted in instabilities in the PAN profile retrieval. This was caused by the incorrect vertical position of the hygropause mapped into the resulting water vapour profile through the Tikhonov-Phillips regularisation constraint. To solve this problem we adopted a 2-step approach. In the first step we use a zero a priori $\mathrm{H}_{2} \mathrm{O}$ profile and a relatively strong regularisation. This leads to a $\mathrm{H}_{2} \mathrm{O}$ profile $\left(\mathrm{H}_{2} \mathrm{O}_{\text {first }}\right)$ with reasonable position of the hygropause but relatively low vertical resolution. Its values are found to be higher than the in situ data between 10 and $12 \mathrm{~km}$.

In the next step with weakened constraint, $\mathrm{H}_{2} \mathrm{O}_{\text {first }}$ is used as the a priori to get the next $\mathrm{H}_{2} \mathrm{O}$ profile. This profile has been used as the "selected" $\mathrm{H}_{2} \mathrm{O}$ a priori in the PAN retrieval. As shown in Fig. 6 the fitted $\mathrm{H}_{2} \mathrm{O}$ vmr profile is very similar to the selected a priori profile above $11 \mathrm{~km}$ but larger at lower altitudes. Both the selected a priori and the fitted profile tend to have some zigzag structure around $12-13 \mathrm{~km}$. Such kind of feature is also present in the in situ data observed by the instruments FLASH and FISH (Fig. 6) just above the hygropause and, thus, seems to be real.

\subsection{PAN cross sections}

Cross sections for PAN have been measured at $295 \mathrm{~K}, 273 \mathrm{~K}$ and $250 \mathrm{~K}$ (Allen et al., 2005a,b) whereas the relevant temperature for our measurements is between $197 \mathrm{~K}$ and $250 \mathrm{~K}$. The cross sections increase from $273 \mathrm{~K}$ to $250 \mathrm{~K}$ by $8 \%$, from $295 \mathrm{~K}$ to $273 \mathrm{~K}$ by $12 \%$. For the PAN profile we extrapolated linearly, using the cross section measured at $273 \mathrm{~K}$ and $250 \mathrm{~K}$, according to the atmospheric temperature profile. 

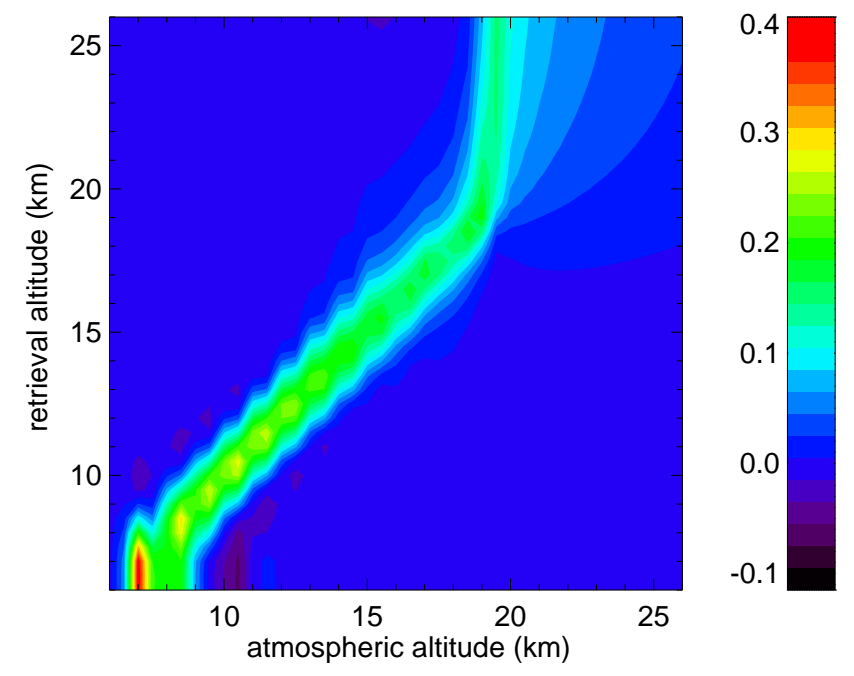

Fig. 8. Averaging kernel for the retrieval of PAN with MIPAS-STR.

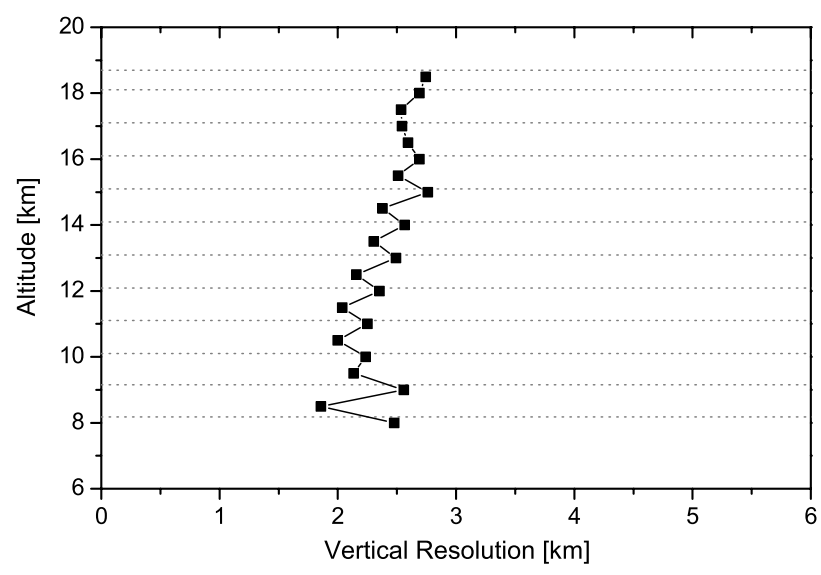

Fig. 9. Achieved vertical resolution of the retrieved PAN profile. The tangent heights are indicated by dotted lines.

\subsection{The resulting PAN-profile}

Figure 7 shows the retrieved profile of PAN from MIPAS-

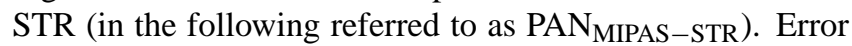
bars indicating the total error (see Sect. 4.7 and Fig. 11) and the noise error are added in the profile. The vmr profile peaks at $10 \mathrm{~km}$ altitude with a value of about $0.14 \mathrm{ppbv}$ and an error of $15 \%$. At $14 \mathrm{~km}$, still 0.04 ppbv of PAN are observed with an error of proximately $22 \%$.

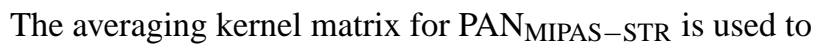
determine the sensitivity of the retrieval at different altitudes (see Fig. 8). The columns of the matrix are the answers of the retrieval to a delta function in the associated altitude. The diagonal structures in the altitude range of the limb sequences between 8 and $18.6 \mathrm{~km}$ is clearly visible in Fig. 8. Below this
Table 2. Three test cases for examination of the spectral fit quality.

\begin{tabular}{lll}
\hline & $\begin{array}{l}\text { A priori } \\
\text { PAN profile }\end{array}$ & $\begin{array}{l}\text { Treatment of PAN } \\
\text { in KOPRAFIT }\end{array}$ \\
\hline $\mathrm{RUN}_{\text {fit }}$ & Model & fitted \\
$\mathrm{RUN}_{\text {limit }}$ & $\mathrm{NO}_{\mathrm{y}}-\mathrm{NO}-\mathrm{NO}_{2}-\mathrm{HNO}_{3}$ & $\begin{array}{l}\text { not fitted } \\
\mathrm{RUN}_{\text {zero }}\end{array}$ \\
Zero & not fitted \\
\hline
\end{tabular}

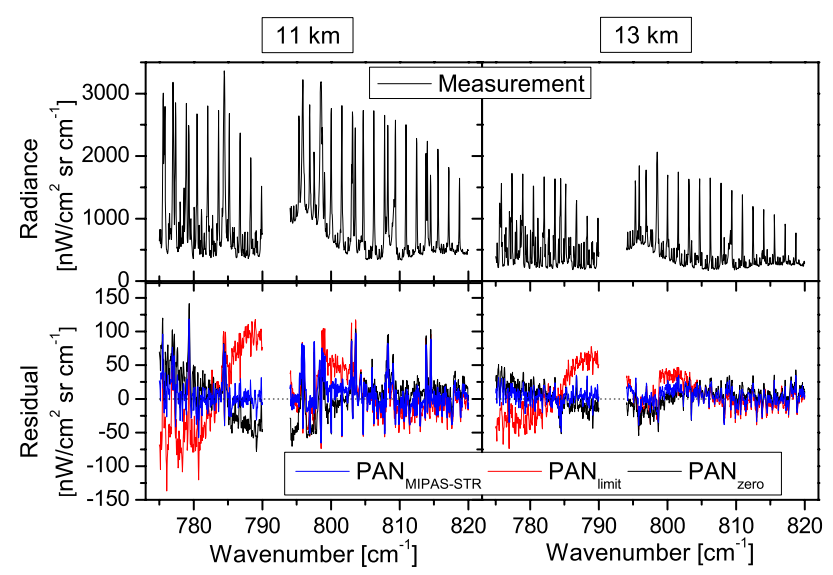

Fig. 10. MIPAS-STR measured spectra in black (top panels) and the residual spectra (forward calculation - measurement) in blue, red and black of RUN $\mathrm{N}_{\text {fit }}$ and the tests $\mathrm{RUN}_{\text {limit }}$ and $\mathrm{RUN}_{\text {zero }}$ (lower panels) at tangent heights of $11 \mathrm{~km}$ (left panels) and $13 \mathrm{~km}$ (right panels).

range no measurements are available. The vertical resolution, determined as FWHM of each column of the averaging kernel matrix is given in Fig. 9. Above the flight level of $19 \mathrm{~km}$ the diagonal structure broadens strongly showing that there the vertical information is strongly reduced compared to the limb-range where a vertical resolution of $2-2.5 \mathrm{~km}$ has been achieved (see Fig. 9).

\subsection{Residual spectra}

We investigate the quality in the spectral domain of the PAN retrieval described in Sect. $4.3\left(\mathrm{RUN}_{\mathrm{fit}}\right)$ in comparison with that resulting from two further approaches (see Table 2). For

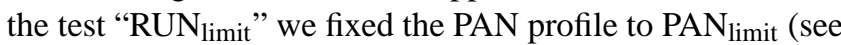
Fig. 2) and retrieved all other parameters as described in Sect. 4.3. The test RUN $\mathrm{N}_{\text {zero }}$ has been handled similarly but all PAN vmrs are fixed to zero.

For all three runs, the residual spectra are shown in the lower panels of Fig. 10 for two selected tangent heights, $11 \mathrm{~km}$ (left part) and $13 \mathrm{~km}$ (right part). The top panels show the corresponding measured spectra. The rms (root mean square) of the residuum is considerately lower $\left[14.8 \mathrm{nW} /\left(\mathrm{cm}^{2} \mathrm{srcm}^{-1}\right)\right]$ for the run $\mathrm{RUN}_{\mathrm{fit}}$, than for $\mathrm{RUN}_{\text {limit }}\left[32.1 \mathrm{nW} /\left(\mathrm{cm}^{2} \mathrm{srcm}^{-1}\right)\right]$ and $\mathrm{RUN}_{\text {zero }}$ 


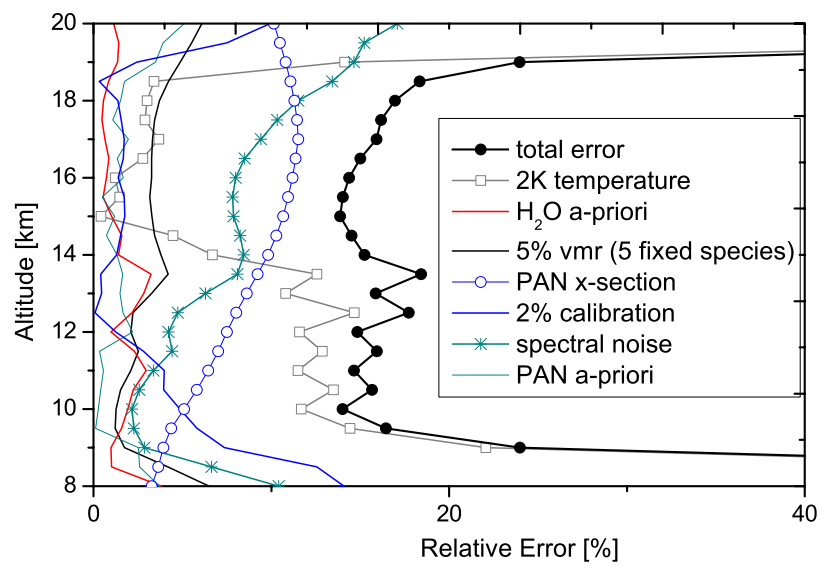

Fig. 11. Estimated total and individual relative errors in PAN MIPAS-STR analysis.

$\left[27.3 \mathrm{nW} /\left(\mathrm{cm}^{2} \mathrm{srcm}^{-1}\right)\right]$. The rms of $\mathrm{RUN}_{\mathrm{fit}}$ is higher than the spectral noise $\left(6 \mathrm{nW} /\left(\mathrm{cm}^{2} \mathrm{srcm}^{-1}\right)\right)$, because the residuum still contains residuals of lines, especially for low tangent heights. The broadband structure similar to the PAN contribution (see Figs. 3 and 4), present in the residua of $R U N_{\text {limit }}$ and $\mathrm{RUN}_{\text {zero }}$, is, however, removed in $\mathrm{RUN}_{\text {fit }}$.

\subsection{Error estimation}

In this section we analyse the effects of various error sources on the retrieved PAN vertical profile. We distinguish instrument-related error sources such as calibration and spectral noise and retrieval-related error sources such as spectroscopy and the errors in the used profiles. Here we consider temperature, water vapour, $\mathrm{CCl}_{4}$ and the five interfering species $\left(\mathrm{CH}_{3} \mathrm{CCl}_{3}\right.$, CFC-113, CFC-22, CFC-11, and $\mathrm{ClONO}_{2}$ ) whose profiles have been kept constant during the PAN retrieval. Figure 11 presents the total error together with the individual errors described in the following paragraphs.

1. Temperature: A comparison of the retrieved vertical temperature profile from MIPAS-STR with that of ECMWF and in situ observations by the Rosemount TDC is shown in Fig. 12. In general, good agreement is found between all profiles, providing us the confidence in the level-1 processing for the spectral band in which PAN is also retrieved. Since the MIPAS-STR temperature is still slightly lower in the comparison, especially in the lower part, the contribution from a $2 \mathrm{~K}$ shift of the temperature profile is considered in the PAN error estimation.

2. Water vapour: Two different $\mathrm{H}_{2} \mathrm{O}$ a priori profiles (test and test ${ }_{2}$ in Fig. 6), are used to estimate the contribution of the $\mathrm{H}_{2} \mathrm{O}$ a priori profile on the PAN error budget. In both a priori test profiles the zigzag at $13 \mathrm{~km}$

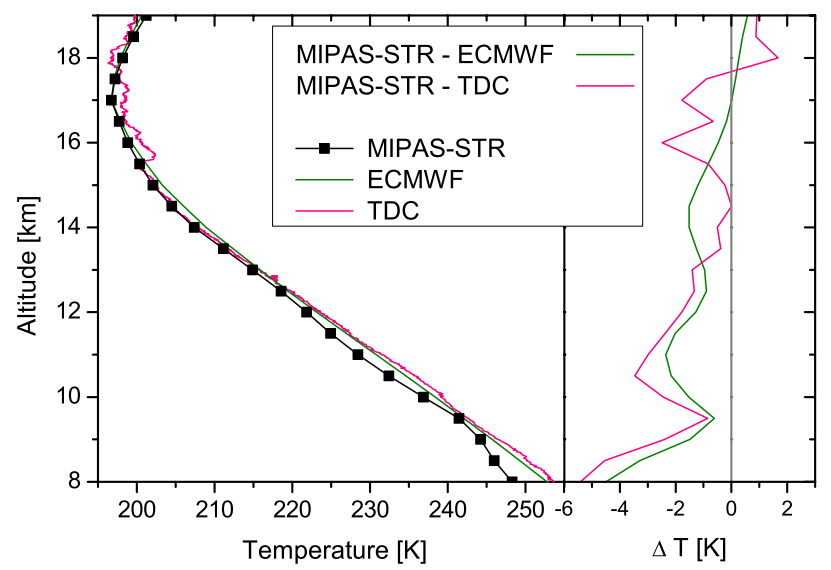

Fig. 12. Comparison of the temperature profile retrieved simultaneously with PAN from MIPAS-STR spectra with that of ECMWF and in situ instrument TDC aboard the Geophysica.

is removed. Additionally, the a priori values in test ${ }_{2}$ have been increased for altitudes below $11 \mathrm{~km}$, adapting the FLASH measurement. Test ${ }_{1}$ only weakly influences PAN MIPAS-STR, whereas test $_{2}$ leads to differences in the order of about $5 \%$.

3. The five pre-determined species: An uncertainty of 5\% in each of the vmr profiles $\left(\mathrm{CH}_{3} \mathrm{CCl}_{3}, \mathrm{CFC}-113, \mathrm{CFC}\right.$ 22, CFC-11, and $\mathrm{ClONO}_{2}$ ), which have been determined in previous steps and kept constant during the PAN retrieval, is assumed. The real profiles of these species are not important, but how good the spectral signatures may be removed from the measured spectra. So the spectroscopic error, normally dominating the error budged, can be omitted. The remaining error shrinks to about $5 \%$.

4. PAN cross sections: To consider atmospheric temperatures lower than $250 \mathrm{~K}$ we linearly extrapolated the cross sections measured at $273 \mathrm{~K}$ and $250 \mathrm{~K}$. For the error from the PAN cross section, we added the temperature dependent term $(\mathrm{T}-250 \mathrm{~K}) \times 0.16 \%$ to the error of $3 \%$ given by Allen et al. (2005b) for $250 \mathrm{~K}$. The first term, roughly $4 \%$ for $25 \mathrm{~K}$ difference is the dominant term at temperatures close to $200 \mathrm{~K}$.

5. Radiometric calibration: An error in the gain calibration of $2 \%$ has been assumed (Friedl-Vallon et al., 2004).

6. Spectral noise: A NESR (noise equivalent signal radiance) of $6 \mathrm{nW} /\left(\mathrm{cm}^{2} \mathrm{srcm}^{-1}\right)$ has been assumed.

Figure 11 presents each individual error contribution together with the total error calculated from these by the root square sum of all individual errors for each altitude. The high relative errors are at altitudes with low vmr values (see 


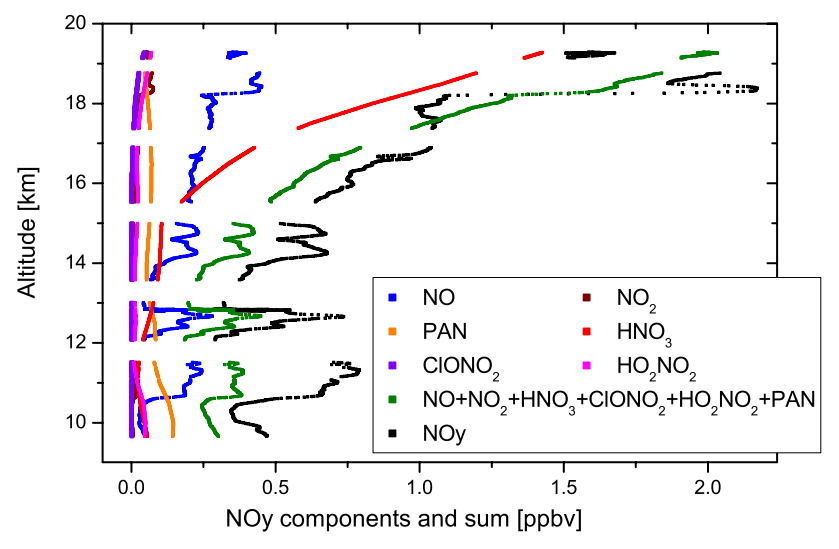

Fig. 13. Comparison of measured $\mathrm{NO}_{\mathrm{y}}$ with the profiles of the individual constituents and their sum.

Fig. 7). In the altitude range spanned by the tangent points from $9 \mathrm{~km}$ to $18 \mathrm{~km}$, the total relative error is between $15 \%$ and $20 \%$. In the lower part (up to about $14 \mathrm{~km}$ ), errors in the temperature and PAN cross section dominate, whereas above spectral noise and PAN cross section are the major error sources. Error bars for the total error are given with the PAN MIPAS-STR profile in Fig. 7.

\section{Discussion}

This work was initiated by the comparison of the MIPAS$\mathrm{STR}_{\mathrm{HNO}}$ profile with the difference profile $\mathrm{NO}_{\mathrm{y}}-\mathrm{NO}$, measured by the in-situ instrument SIOUX. The disagreement between the two profiles posed the question, which of the constituents of $\mathrm{NO}_{\mathrm{y}}$ have to be considered additionally. The profiles of $\mathrm{ClONO}_{2}$ and $\mathrm{HO}_{2} \mathrm{NO}_{2}$ were retrieved from the MIPAS-STR spectra, and $\mathrm{NO}_{2}$ was calculated from $\mathrm{O}_{3}$ and NO. However, the consideration of those gases did not change the situation, as their vmrs are very small. So we tried successfully to retrieve PAN vmrs from the MIPASSTR spectra. But the retrieved PAN profile only accounts for a sixth to a half (depending on the height) of the deficit $\mathrm{NO}_{\mathrm{y}}-\mathrm{NO}-\mathrm{NO}_{2}-\mathrm{HNO}_{3}-\mathrm{ClONO}_{2}-\mathrm{HO}_{2} \mathrm{NO}_{2}$. In Fig. 13 we show all derived profiles of the individual constituents of $\mathrm{NO}_{\mathrm{y}}$, their sum and the measured $\mathrm{NO}_{\mathrm{y}}$ profile. In this figure, the MIPAS-STR profiles are interpolated to the in situ measurement altitudes, the data gaps result from calibration cycles of the SIOUX instrument.

We also degraded all in situ profiles to a resolution, as if they had been measured by MIPAS-STR. This was done according to Eq. (4) (e.g., von Clarmann et al., 2007b).

$\hat{\boldsymbol{x}}=\boldsymbol{x}_{a}+\mathbf{A}\left(\boldsymbol{x}-\boldsymbol{x}_{a}\right)$

where $\boldsymbol{x}$ is the in situ profile (replacing the true atmospheric state in the original Equation), $\boldsymbol{x}_{a}$ is the a priori profile, and

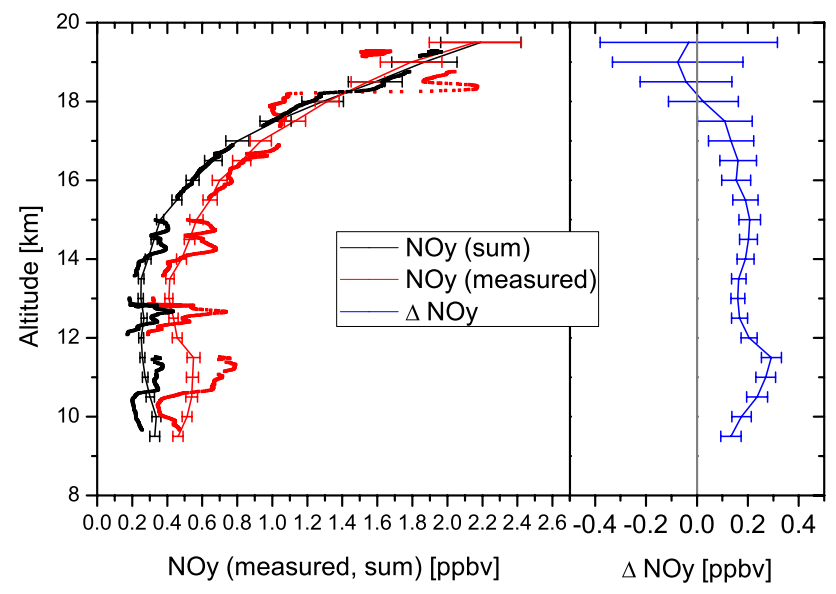

Fig. 14. Comparison of measured $\mathrm{NO}_{\mathrm{y}}$ with the sum of the individual constituents. All in situ profiles are degraded to the MIPAS-STR vertical resolution

$\mathbf{A}$ is the averaging kernel as given in Eq. (3). The left side $\hat{\boldsymbol{x}}$ is the profile virtually measured by MIPAS-STR. As a priori profiles for $\mathrm{NO}$ and $\mathrm{NO}_{2}$ we used their profiles given in the climatology (Remedios et al., 2007b). For $\mathrm{NO}_{\mathrm{y}}$ we used the sum of $\mathrm{HNO}_{3}$ and $\mathrm{ClONO}_{2}$. As the averaging kernels result from a real retrieval they are not available. But as already described near Eq. (3), the averaging kernel reflects the vertical spacing of the tangent points. This results in a similarity of the averaging kernels of the different trace gases. We therefore can use the averaging kernel of the PAN retrieval to simulate the $\mathrm{NO}_{\mathrm{y}}, \mathrm{NO}$, and $\mathrm{NO}_{2}$ measurements. Figure 14 shows the profile of $\mathrm{NO}_{\mathrm{y}}$ together with the sum of $\mathrm{NO}, \mathrm{NO}_{2}$, $\mathrm{HNO}_{3}, \mathrm{ClONO}_{2}, \mathrm{HO}_{2} \mathrm{NO}_{2}$, and PAN in the left panel. We give both, the degraded and the not degraded profiles. 1Sigma error bares are added to the degraded profiles. The error of the sum is the root square sum of the errors of the individual gases. In the left panel we show the (degraded) residual $\mathrm{NO}_{\mathrm{y}}-\mathrm{NO}-\mathrm{NO}_{2}-\mathrm{HNO}_{3}-\mathrm{ClONO}_{2}-\mathrm{HO}_{2} \mathrm{NO}_{2}-\mathrm{PAN}$. The error bares also give the $1-\sigma$ error, calculated as the root square sum of the errors of the individual gases.

At altitudes above the tropopause, where the tropospheric constituents of $\mathrm{NO}_{\mathrm{y}}$ can be neglected, the profile of $\mathrm{NO}_{\mathrm{y}}$ agrees well with the calculated sum. This gives us confidence in the accuracy of the measurements. Below, the discrepancy reaches $0.29 \pm 0.04 \mathrm{ppbv}$ at $11.5 \mathrm{~km}$ (see Fig. 14). We therefore conclude that not all contributing reactive nitrogens have been accounted for in the sum.

Murphy et al. (2004) report on two compounds $\left(\mathrm{HO}_{2} \mathrm{NO}_{2}\right.$ and $\mathrm{CH}_{3} \mathrm{O}_{2} \mathrm{NO}_{2}$ ) which become important at low temperatures in the upper troposphere. They determined their contribution to $\mathrm{NO}_{\mathrm{y}}$ to be $30 \%$ and more at temperatures below $230 \mathrm{~K}$. This could explain the discrepancy, as these compounds are measured in the sum $\mathrm{NO}_{y}$, but only $\mathrm{HO}_{2} \mathrm{NO}_{2}$ could be considered in the calculated sum. 


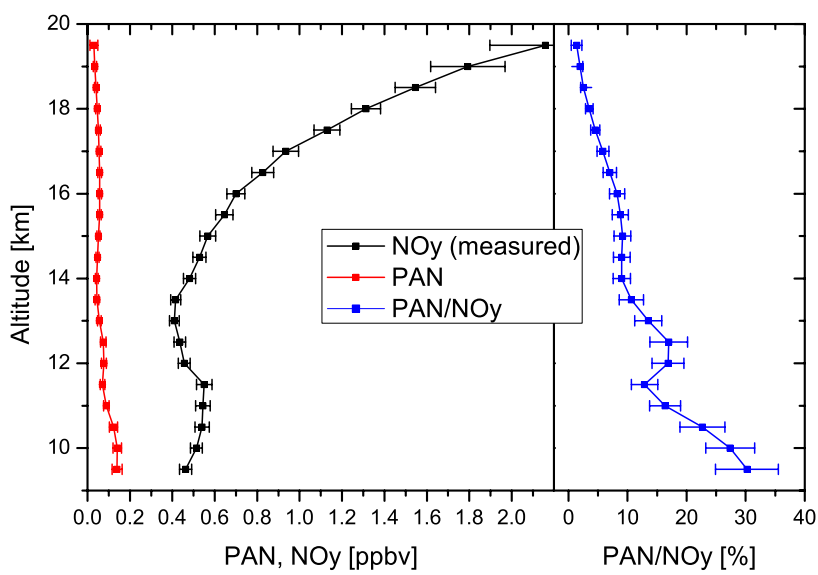

Fig. 15. Comparison of measured $\mathrm{NO}_{\mathrm{y}}$ with the PAN profile and the relative contribution of PAN to $\mathrm{NO}_{\mathrm{y}}$. The profile of $\mathrm{NO}_{\mathrm{y}}$ is degraded to the vertical resolution of the PAN profile.

In Fig. 15 we show the relative contribution of PAN to $\mathrm{NO}_{\mathrm{y}}$. In the left panel we show the (degraded) profiles, and in the right panel we show there ratio. The ratio peaks $30 \%$ at $9.5 \mathrm{~km}$. Roberts et al. (2004) measured ratios of more than $60 \%$ in long-range transported Asian pollution plumes. Singh (1996) report $23 \%$ in the western subtropical south Atlantic for the altitude range $7-12 \mathrm{~km}$. The later is in accordance with our measurements in the same region. Singh (1996) sorted their measurements according to the CO vmr in "influenced by anthropogenic pollution" and "relatively clean background". The corresponding median PAN vmrs show no significant difference above $8 \mathrm{~km}$ ( $65 \mathrm{pptv}$ and $45 \mathrm{pptv}$ ), and are somehow in agreement with our measurements. The "polluted" median $\mathrm{NO}_{\mathrm{y}} \mathrm{vmr}(340 \mathrm{pptv}-100 \mathrm{pptv}$ for "clean") is increased by a factor of three due to the pollution, but is still lower than our measurement of about 500 pptv $(9-12 \mathrm{~km})$. The PAN to $\mathrm{NO}_{\mathrm{y}}$ ratio of the "polluted" measurements (20\%) is only little smaller than for the whole data set and thus still in accordance with our value. However, compared to Glatthor et al. (2007,0.33 ppbv@8 km and 0.23 ppbv @ $11 \mathrm{~km}$ ) who use the same method, our PAN vmrs are smaller.

\section{Summary}

We investigated the retrieval of the vertical profile $(8-19 \mathrm{~km})$ of PAN using MIPAS-STR emission spectra obtained in the tropics in February 2005. The largest peak in the retrieved PAN vmr profile is located at $10 \mathrm{~km}$ altitude with an amount of about $0.14 \mathrm{ppbv}$. Above $10 \mathrm{~km}$ PAN decreases with a secondary smaller maximum at $16 \mathrm{~km}(\approx 0.06 \mathrm{ppbv})$. The total relative error is estimated to be about $15-20 \%$ between 9 and $18 \mathrm{~km}$.
We used simultaneous in situ measurements to derive the ratio $\mathrm{PAN} / \mathrm{NO}_{\mathrm{y}}$ which peaks around $30 \%$ at $9.5 \mathrm{~km}$. We calculated the sum of all measured (in-situ and remote) $\mathrm{NO}_{\mathrm{y}}$ constituents $\left(\mathrm{NO}, \mathrm{NO}_{2}, \mathrm{HNO}_{3}, \mathrm{ClONO}_{2}, \mathrm{HO}_{2} \mathrm{NO}_{2}\right.$, and $\mathrm{PAN}$ ) and compared it to the measured total $\mathrm{NO}_{\mathrm{y}}$. The deficit peaks at $0.29 \pm 0.04 \mathrm{ppbv}$ at $11.5 \mathrm{~km}$.

Acknowledgements. Financial support for this project by the European Space Agency (contracts 10249/01/NL/SF and 16039/02/NL/SF) and the European Commission (contract EVK2CT-2001-00122) is acknowledged. We thank NILU for providing ECMWF analysis data via the NADIR database. We thank the colleagues of FISH, FLASH, FOZAN, SIOUX, and TDC for providing their measurements.

Edited by: V. F. McNeill

\section{References}

Allen, G., Remedios, J. J., Newnham, D. A., Smith, K. M., and Monks P. S.: Improved mid-infrared cross-sections for peroxyacetyl nitrate (PAN) vapour, Atmos. Chem. Phys., 5, 47-56, 2005a, http://www.atmos-chem-phys.net/5/47/2005/.

Allen, G., Remedios, J. J., and Smith, K. M.: Low temperature midinfrared cross-sections for peroxyacetyl nitrate (PAN) vapour, Atmos. Chem. Phys., 5, 3153-3158, 2005b, http://www.atmos-chem-phys.net/5/3153/2005/.

Finlayson-Pitts, B. J. and Pitts, J. N.: Chemistry of the upper and lower atmosphere, Academic Press: A Harcount Science and Technology Company, 525 B Street, Suite 1900, San Diego, California, 92101-4495, USA, 2000.

Coheur, P.-F., Herbin, H., Clerbaux, C., Hurtmans, D., Wespes, C., Carleer, M., Turquety, S., Rinsland, C. P., Remedios, J., Hauglustaine, D., Boone, C. D., and Bernath, P. F.: ACE-FTS observation of a young biomass burning plume: first reported measurements of $\mathrm{C} 2 \mathrm{H} 4, \mathrm{C} 3 \mathrm{H} 6 \mathrm{O}, \mathrm{H} 2 \mathrm{CO}$ and PAN by infrared occultation from space, Atmos. Chem. Phys., 7, 5437-5446, 2007, http://www.atmos-chem-phys.net/7/5437/2007/.

Day, D. A., Wooldridge, P. J., Dillon, M. B., Thornton, J. A., and Cohen, R. C.: A thermal dissociation laser-induced fluorescence instrument for in situ detection of $\mathrm{NO} 2$, peroxy nitrates, alkyl nitrates, and $\mathrm{HNO}_{3}$, J. Geophys. Res., 107(D6), 4046, doi:10.1029/2001JD000779, 2002.

Fahey, D. W., Eubank, C. S., Hbler, G., and Fehsenfeld, F. C.: Evaluation of a catalytic reduction technique for the measurement of of total reactive odd-nitrogen $\mathrm{NO}_{\mathrm{y}}$ in the atmosphere, J. Atmos. Chem., 3, 435-468, 1985.

Fischer, H. and Oelhaf, H.: Remote sensing of vertical profiles of atmospheric trace constituents with MIPAS limb-emission spectrometers, Appl. Opt., 35, 2787-2796, 1996.

Flaud, J.-M., Piccolo, C., Carli, B., Perrin, A., Coudert, L. H., Teffo, J.-L., and Brown, L. R.: Molecular line parameters for the MIPAS (Michelson Interferometer for Passive Atmospheric Sounding) experiment, Atmos. Oceanic Opt., 16, 172-182, 2003.

Friedl-Vallon, F., Maucher, G., Seefeldner, M., Trieschmann, O., Kleinert, A., Lengel, A., Keim, C., Oelhaf, H., and Fischer, H.: Design and Characterization of the Balloon-Borne Michelson 
Interferometer for Passive Atmospheric Sounding (MIPAS-B2), Appl. Opt. 43, 3335-3355, 2004.

Gaffney, J. S., Bornick, R. M., Chen, Y.-H., and Marley, N. A.: Capillary gas chromatographic analysis of nitrogen dioxide and PANs with luminol chemiluminescent detection, Atmos. Environ., 32, 1445-1454, 1998.

Glatthor, N., von Clarmann, T., Fischer, H., Funke, B., Grabowski, U., Höpfner, M., Kellmann, S., Kiefer, M., Linden, A., Milz, M., Steck, T., and Stiller, G. P.: Global peroxyacetyl nitrate (PAN) retrieval in the upper troposphere from limb emission spectra of the Michelson Interferometer for Passive Atmospheric Sounding (MIPAS), Atmos. Chem. Phys., 7, 2775-2787, 2007, http://www.atmos-chem-phys.net/7/2775/2007/.

Grooß, J.-U., Günther, G., Müller, R., Konopka, P., Bausch, S., Schlager, H., Voigt, C., Volk, C. M., Toon, G. C.: Simulation of Denitrification and Ozone Loss for the Arctic Winter 2002/2003, Atmos. Chem. Phys. 5, 1437-1448, 2005.

Hansel. A. and Wisthaler, A.: A method for real-time detection of PAN, PPN, and MPAN in ambient air, Geophys. Res. Lett., 27, 895-898, 2000.

Hansel, A., Jordan, A., Holzinger, R., Prazeller, P., Vogel, W., and Lindinger, W.: Proton transfer reaction mass spectrometry: online trace gas analysis at the ppb level, Int. J. Mass Spectrom. Ion Processes, 149/150, 609-619, 1995.

Hanst, P. L., Wong, N. W., and Bragin, J.: A long-path infrared study of Los Angeles smog, Atmos. Environ., 16, 969-981, 1982.

Holzinger, R., Williams, J., Salisbury, G., Kluepfel, T., de Reus, M., Traub, M., Crutzen, P. J., and Lelieveld, J.: Oxygenated compounds in aged biomass burning plumes over the Eastern Mediterranean: evidence for strong secondary production of methanol and acetone, Atmos. Chem. Phys., 5, 39-46, 2005, http://www.atmos-chem-phys.net/5/39/2005/.

Höpfner, M., Blom, C. E., Clarmann, T.v., Fischer, H., Glatthor, N., Gulde, T., Hase, F., Keim, C., Kimmig, W., Lessenich, K., Piesch, C., Sartorius, C., and Stiller, G. P.: MIPAS-STR data analysis of APE-GAIA measurements. Paper presented in IRS 2000: Current Problems in Atmospheric Radiation, W. L. Smith and Yu. M. Timofeyev (Editors), A. Deepak Publishing, Hampton, Virginia. 1136-1139, 2000.

Höpfner, M., von Clarmann, T., Fischer, H., Funke, B., Glatthor, N., Grabowski, U., Kellmann, S., Kiefer, M., Linden, A., Milz, M., Steck, T., Stiller, G. P., Bernath, P., Blom, C. E., Blumenstock, Th., Boone, C., Chance, K., Coffey, M. T., Friedl-Vallon, F., Griffith, D., Hannigan, J. W., Hase, F., Jones, N., Jucks, K. W., Keim, C., Kleinert, A., Kouker, W., Liu, G. Y., Mahieu, E., Mellqvist, J., Mikuteit, S., Notholt, J., Oelhaf, H., Piesch, C., Reddmann, T., Ruhnke, R., Schneider, M., Strandberg, A., Toon, G., Walker, K. A., Warneke, T., Wetzel, G., Wood, S., and Zander, R.: Validation of MIPAS $\mathrm{ClONO}_{2}$ measurements, Atmos. Chem. Phys., 7, 257-281, 2007, http://www.atmos-chem-phys.net/7/257/2007/.

Horowitz, L. W., Walters, S., Mauzerall, D. L., Emmons, L. K., Rasch, P. J., Granier, C., Tie, X., Lamarque, J.-F., Schultz, M. G., and Brasseur, G. P.: A global simulation of tropospheric ozone and related tracers: Description and evaluation of MOZART, version 2, J. Geophys. Res., 108(D24), 4784, doi:10.1029/2002JD002853, 2003.

Keim, C., Blom, C. E., Von Der Gathen, P., Gulde, T., Höpfner,
M., Liu, G. Y., Oulanovski, A., Piesch, C., Ravegnani, F., Sartorius, C., Schlager, H., and Volk, C. M.: Validation of MIPASENVISAT by correlative measurements of MIPAS-STR, Proc. ACVE-2 meeting, 3-7 May 2004, Frascati, Italy, 2004, ESA SP562

Kirchener, F., Mayer-Figge, A., Zabel, F., and Becker, K. H.: Thermal stability of peroxynitrates, Int. J. Chem. Kinet., 31, 127-144, 1999.

Lovelock, J. E.. Ionization methods for the analysis of gases and vapours, Anal. Chem., 33, 162-178, 1961.

Moore, D. P. and Remedios, J. J.: Growth rates of stratospheric HCFC-22, Atmos. Chem. Phys., 8, 73-82, 2008, http://www.atmos-chem-phys.net/8/73/2008/.

Murphy, J.G., Thornton, J. A., Wooldridge, P. J., Day, D. A., Rosen, R. S., Cantrell, C., Shetter, R. E., Lefer, B., and Cohen, R. C.: Measurements of the sum of $\mathrm{HO}_{2} \mathrm{NO}_{2}$ and $\mathrm{CH}_{3} \mathrm{O}_{2} \mathrm{NO}_{2}$ in the remote troposphere, Atmos. Chem. Phys., 4, 377-384, 2004 http://www.atmos-chem-phys.net/4/377/2004/.

Müller, K. P. and Rudolph, J.: An automated technique for the measurement of peroxyacetylnitrate in ambient air at ppb and ppt levels, Int. J. Environ. Anal. Chem., 37, 253-262, 1989.

Phillips, C.: A Technique for the Numerical Solution of Certain Integral Equations of the First Kind, J. Assoc. Comput. Math., 9, 84-97, 2003.

Piesch, C., Gulde, T., Sartorius, C., Friedl-vallon, F., Seefeldner, M., Wölfel, M., Blom, C. E., and Fischer, H.: Design of a MIPAS instrument for high-altitude aircraft, Proc. of the 2nd Internat. Airborne Remote Sensing Conference and Exhibition, ERIM, Ann Arbor, MI, Vol. II, 199-208, 1996.

Remedios, J. J., Allen, G., Waterfall, A. M., Oelhaf, H., Kleinert, A., and Moore, D. P.: Detection of organic compound signatures in infra-red, limb emission spectra observed by the MIPAS-B2 balloon instrument, Atmos. Chem. Phys., 7, 1599-1613, 2007, http://www.atmos-chem-phys.net/7/1599/2007/.

Remedios, J. J., Leigh, R. J., Waterfall, A. M., Moore, D. P., Sembhi, H., Parkes, I., Greenhough, J., Chipperfield, M.P., and Hauglustaine, D.:MIPAS reference atmospheres and comparisons to V4.61/V4.62 MIPAS level 2 geophysical data sets, Atmos. Chem. Phys. Discuss., 7, 9973-10 017, 2007.

Roberts, J. M., Flocke, F., Chen, G., Gouw, J., Holloway, J. S., Höubler, G., Neuman, J. A., Nicks, D. K., Nowak, J. B., Parrish, D. D., Ryerson, T. B., Sueper, D. T., Warneke, C., and Fehsenfeld, F. C.: Measurement of peroxycarboxylic nitric anhydrides (PANs) during the ITCT 2K2 aircraft intensive experiment, J. Geophys. Res., 109, D23S21, doi:10.1029/2004JD004960, 2004.

Ruggaber, A., Plugi, R., and Nakajima, T.: Modelling of radiation quantities and photolysis frequencies in the troposphere, J. Atmos. Chem., 18, 171-210, 1994.

Schlager, H., et al.: In situ observations of air traffic emission signatures in the North Atlantic flight corridor, J. Geophys. Res., 102(D9), 10 739-10 750, 1997.

Schmitt, J.: Development of a NO/NO $\mathrm{NO}_{\mathrm{y}}$ measurement system for the high altitude aircraft Geophysica, Dissertation University of Munich, DLR Research Report 2003-21, pp160, ISRN DLR-200321,2003

Singh, H. B.: Reactive nitrogen in the troposphere - chemistry and transport of $\mathrm{NO}_{\mathrm{x}}$ and PAN, Envir. Sci. Technol., 21, 320-327, 1987. 
Singh, H. B., Herlth, D., Kolyer, R., Chatfield, R., Viezee,W., Salas, L. J., Chen, Y., Bradshaw, J. D., Sandholm, S. T., Talbot, R., Gregory, G. L., Anderson, B., Sachse, G. W., Browell, E., Bachmeier, A. S., Blake, D. R., Heikes, B., Jacob, D., and H. E. Fuelberg: Impact of biomass burning emissions on the composition of the South Atlantic troposphere: Reactive nitrogen and ozone, J. Geophys. Res., 101(D19), 24 203-24 219, 1996.

Sitnikov, N. M., Yushkov, V. A., Afchine, A. A., Korshunov, L. I., Astakhov, V. I.,Ulanovskii, A. E., Kraemer,M., Mangold, A., Schiller, C., and Ravegnani,F.: The FLASH Instrument for Water Vapor Measurements on Board the High-Altitude Airplane, Instrum. Exp. Tech+, 50(1), 113-121, 2007.

Slusher, D. L., Huey, L. G., Tanner, D. J., Flocke, F. M., and Roberts, J. M.: A thermal dissociation-chemical ionization mass spectrometry (TD-CIMS) technique for the simultaneous measurement of peroxyacyl nitrates and dinitrogen pentoxide, J. Geophys. Res., 109, D19315, doi:10.1029/2004JD004670, 2004.

Stephens, E. R., Hanst, P. L., Dörr, R. C., and Scott, W. E.: Reactions of nitrogen dioxide and organic compounds in air, Ind. Eng. Chem., 48, 1498-1504, 1956.

Stiller, G. P. (Editor) with contributions from v. Clarmann, T., Dudhia, A., Echle, G., Funke, B., Glatthor, N., Hase, F., Höpfner, M., Kellmann, S., Kemnitzer, H., Kuntz, M., Linden, A., Linder, M., Stiller, G. P., and Zorn, S.: The Karlsruhe Optimized and Precise Radiative Transfer Algorithm (KOPRA), vol. FZKA 6487 of Wissenschaftliche Berichte, Forschungszentrum Karlsruhe, 2000.

Stiller, G. P., von Clarmann, T., Brühl, C., Fischer, H., Funke, B., Glatthor, N., Grabowski, U., Höpfner, M., Jöckel, P., Kellmann, S., Kiefer, M., Linden, A., Löpez-Puertas, M., Mengistu Tsidu, G., Milz, M., Steck, T., and Steil, B.: Global distributions of $\mathrm{HO}_{2} \mathrm{NO}_{2}$ as observed by the Michelson Interferometer for Passive Atmospheric Sounding (MIPAS), J. Geophys. Res., 112, D09314, doi:10.1029/2006JD007212, 2007.

Talukdar, R. K., Burkholder, J. B., Schmoltner, A., Roberts, J. M., Wilson, R. R., and Ravishankara, A. R.: Investigation of the loss processes for peroxyacetyl nitrate in the atmosphere: UV photolysis and reaction with OH, J. Geophys. Res., 100(D7), $14163-$ $14173,1995$.

Tanimoto, H.: The seasonal variation of atmospheric peroxyacetyl nitrate (PAN) in east Asia observed by GC/NICI-MS technique, Department of Chemistry, Graduate School of Science, The University of Tokyo, Ph.D. thesis, 2001.

Tikhonov, A.: On the Solution of Incorrectly Stated Problems and a Method of Regularisation, Dokl. Acad. Nauk SSSR, 151, 501504, 1963.

Ulanovsky, A. E., Yushkov, V. A., Sitnikov, N. M., and Ravegnani, F.: The FOZAN-II fast-response chemiluminescent airborne ozone analyzer, Instruments and Experimental Techniques, 44 (2), 249-256, 2001.
Voigt, C., Schlager, H., Luo, B. P., Drnbrack, A., Roiger, A., Stock, P., Curtius, J., Vssing, H., Borrmann, S., Davies, S., Konopka, P., Schiller, C., Shur, G., Peter, T.: Nitric Acid Trihydrate (NAT) Formation at Low NAT Supersaturation in Polar Stratospheric Clouds (PSCs), Atmos. Chem. Phys., 5, 1371-1380, 2005, http://www.atmos-chem-phys.net/5/1371/2005/.

Voigt, C., Schlager, H., Ziereis, H., Krcher, B., Luo, B.P., Schiller, C., Krämer, M., Popp, P.J., Irie, H., Kondo, Y., Nitric acid in cirrus clouds. Geophys. Res. Lett., 33, L05803, doi:10.1029/2005GL025159, 2006.

von Clarmann, T., Glatthor, N., Koukouli, M. E., Stiller, G. P., Funke, B., Grabowski, U., Höpfner, M., Kellmann, S., Linden, A., Milz, M., Steck, T., and Fischer, H.: MIPAS measurements of upper tropospheric $\mathrm{C} 2 \mathrm{H} 6$ and $\mathrm{O} 3$ during the southern hemispheric biomass burning season in 2003, Atmos. Chem. Phys., 7, 5861-5872, 2007,

http://www.atmos-chem-phys.net/7/5861/2007/.

von Clarmann, T. and Grabowski, U.: Elimination of hidden a priori information from remotely sensed profile data, Atmos. Chem. Phys., 7, 397-408, 2007,

http://www.atmos-chem-phys.net/7/397/2007/.

Wang, D. Y., Hpfner, M., Mengistu Tsidu, G., Stiller, G. P., von Clarmann, T., Fischer, H., Blumenstock, T., Glatthor, N., Grabowski, U., Hase, F., Kellmann, S., Linden, A., Milz, M., Oelhaf, H., Schneider, M., Steck, T., Wetzel, G., Lpez-Puertas, M., Funke, B., Koukouli, M. E., Nakajima, H., Sugita, T., Irie, H., Urban, J., Murtagh, D., Santee, M. L., Toon, G., Gunson, M. R., Irion, F. W., Boone, C. D., Walker, K., and Bernath, P. F.: Validation of nitric acid retrieved by the IMK-IAA processor from MIPAS/ENVISAT measurements, Atmos. Chem. Phys., 7, 721-738, 2007, http://www.atmos-chem-phys.net/7/721/2007/.

Warneck, P.: Chemistry of the natural atmosphere (2nd edition): Academic Press: A Harcount Science and Technology Company, 525 B Street, Suite 1900, San Diego, California, 92101-4495, USA, 1999.

Zöger, M., Schiller, C., and Eicke, N.: Fast in-situ hygrometers: a new family of balloon-borne and airborne Lyman- $\alpha$ photofragment fluorescence hygrometers, J. Geophys. Res., 104, 1807$1816,1999$.

Ziereis, H., Schlager H., Schulte P., van Velthoven P., and Slemr F., Distributions of $\mathrm{NO}, \mathrm{NOx}$, and $\mathrm{NO}_{\mathrm{y}}$ in the upper troposphere and lower stratosphere between 28 and $61^{\circ} \mathrm{N}$ during POLINAT 2, J. Geophys. Res., 105, 3653-3664, 2000. 